\title{
First report of Meloidogyne incognita infecting white Pitahaya plants
}

\author{
Victor Hugo Moura de Souza ${ }^{1}$ Mário Massayuki Inomoto², \\ Aline Mayara Gonçalves Barros Silva ${ }^{3}$, Tiarla Graciane Souto ${ }^{4}$
}

\begin{abstract}
In July 2020, during a survey carried out in a small farm located in Laranjal Paulista, state of São Paulo (Brazil), more than 20 white pitahaya plants [Hylocereus undatus (Haw.) Britton and Rose (syn. Selenicereus undatus (Haw.) D.R. Hunt] were found with stunting symptoms and showing chlorotic-yellowish stems, some of them already decaying. Roots exhibited numerous galls, indicating Meloidogyne sp. infection. Nematodes were recovered from $200 \mathrm{~cm}^{3}$ and $7 \mathrm{~g}$ of roots: 1.7 Meloidogyne juveniles $\left(\mathrm{J}_{2}\right)$ per $\mathrm{cm}^{3}$ of soil and 954 eggs $+\mathrm{J}_{2}$ per $\mathrm{g}$ of roots were found. The perineal pattern of 10 females pointed to M. incognita. Additionally, esterase phenotype was obtained through isozyme electrophoresis, using another 10 females, which identified M. incognita. To our knowledge, this is the first report of M. incognita infesting pitahaya plants (Hylocereus spp.) and, based on our results, $M$. incognita could be a potential threat to the crop.

Index terms: Diagnosis; dragon fruit; Hylocereus undatus; root-knot nematode; morphology; esterase phenotype.

\section{Primeiro relato de Meloidogyne incognita em Pitaia-branca}

Corresponding author: victorhugomour@gmail.com

Received: July 01, 2021 Accepted: September 01, 2021

Copyright: All the contents of this journal, except where otherwise noted, is licensed under a Creative Commons Attribution License.
Resumo - Em julho de 2020, durante visita em área de pequeno produtor localizada em Laranjal Paulista, São Paulo (Brasil), foram observadas mais de 20 plantas de pitaia-branca [Hylocereus undatus (Haw.) Britton e Rose (syn. Selenicereus undatus (Haw.) D.R. Hunt] apresentando enfezamento e cladódios cloróticos, com porções do caule em declínio. As raízes exibiam numerosas galhas, indicando típica infecção por Meloidogyne sp.. Nematoides foram recuperados de amostras de solo $\left(200 \mathrm{~cm}^{3}\right)$ e $7 \mathrm{~g}$ de raiz: 1,7 juvenis $\left(\mathrm{J}_{2}\right)$ por $\mathrm{cm}^{3}$ de solo, e 954 ovos $+\mathrm{J}_{2}$ de Meloidogyne por grama de raiz foram obtidos. O padrão perineal de 10 fêmeas apontou para M. incognita. Adicionalmente, o fenótipo de esterase foi obtido por meio de eletroforese de isoenzima. Essa foi realizada com 10 fêmeas adicionais, confirmando a identificação por $M$. incognita. Ao nosso conhecimento, este é o primeiro relato de M. incognita infestando plantas de pitaia (Hylocereus spp.). e, baseado em nossa observação em campo, M. incognita pode ser um patógeno potencial a esta cultura.

Termos para indexação: Diagnose; fruta-do-dragão; Hylocereus undatus; nematoide de galhas; morfologia; eletroforese de isoenzimas.

\section{$(\mathrm{cc}) \mathbf{E Y}$}

\footnotetext{
${ }^{1}$ Post-Doctoral researcher, Department of Plant Pathology and Nematology, Escola Superior de Agricultura "Luiz de Queiroz" - University of São Paulo - Piracicaba, Brazil. Email: victorhugomour@gmail.com (ORCID 0000-0002-7576-4676)

${ }^{2}$ Professor, Department of Plant Pathology and Nematology, Escola Superior de Agricultura "Luiz de Queiroz" - University of São Paulo Piracicaba, Brazil. Email: inomoto@usp.br (ORCID 0000-0001-9870-8194)

${ }^{3} \mathrm{PhD}$ student in Plant Pathology, Department of Plant Pathology and Nematology, Escola Superior de Agricultura "Luiz de Queiroz" University of São Paulo - Piracicaba, Brazil. Email: alinesilvaagro@gmail.com (ORCID 0000-0002-7669-3363)

${ }^{4} \mathrm{PhD}$ student in Plant Pathology, Department of Plant Pathology and Nematology, Escola Superior de Agricultura "Luiz de Queiroz" University of São Paulo - Piracicaba, Brazil. Email: tiarla.souto@gmail.com ${ }^{\text {(ORCID 0000-0002-5940-7716) }}$
} 
Pitahaya or pitaya (Hylocereus spp. and Selenicereus spp .) is a native American cactus that produces a sweet fruit known as dragon fruit, which is very appreciated due to its attractive color and pleasant taste. Therefore, some pitahaya species have been cultivated in many countries, mainly in the tropics (ORTIZ-HERNÁNDEZ; CARRILLO-SALAZAR, 2012). In Brazil, the production of this exotic fruit is relatively recent, starting in 2005. Recent data have pointed that the state of São Paulo leads production and cropped area in the country (NUNES et al., 2014; NEPOMOCENO et al., 2019; PROHORT, 2019). White pitahaya [Hylocereus. undantus (Haw.) Britton and Rose (syn. Selenicereus undatus (Haw.) D.R. Hunt)] is the most cultivated species, and is characterized by its white pulp and pink/red color peel (ORTIZ-HERNÁNDEZ; CARRILLO-SALAZAR, 2012; DUARTE et al., 2015). White pitahaya has recently gained attention due to its probable health benefits, and a study with mice fed with high-fat diet found that its juice attenuates insulin resistance and hepatic steatosis (SONG et al., 2016).
As pitahaya cultivation is recent in Brazil, reports on the occurrence of diseases are vital to support farmers. Among plant pathogens, parasitic nematodes are commonly found in farms and are major pests to Brazilian agriculture, notably the root-knot nematode (Meloidogyne spp.). Until recently, no reports of these pests infesting pitahaya were available. However, in 2020, M. javanica (Treub 1882) Chitwood 1949 was reported infesting yellow pitahaya Hylocereus megalanthus (K. Schum. ex Vaupel) Ralf Bauer [syn. S. megalanthus (K. Schum. ex Vaupel) Moran] in Brazil (NASCIMENTO et al., 2020). The authors observed several galls in the root system, especially in secondary ones. Their study brings an alert about the occurrence of Meloidogyne species in pitahaya crops. However, no additional information is currently available addressing this subject in Brazil.

In July 2020, during a survey carried out in a small farm located in Laranjal Paulista, state of São Paulo (Brazil), more than $20 \mathrm{H}$. undatus plants were found with stunting symptoms and showing chloroticyellowish stems, some of them already decaying (Fig. 1a). Roots exhibited numerous galls, indicating Meloidogyne sp. infection (Fig. 1b). In addition, galled roots were observed in numerous other crops in the area, including bell pepper (Capsicum annuum L.), yellow passionfruit (Passiflora edulis Sims f. flavicarpa Deg.) and papaya (Carica papaya L.).
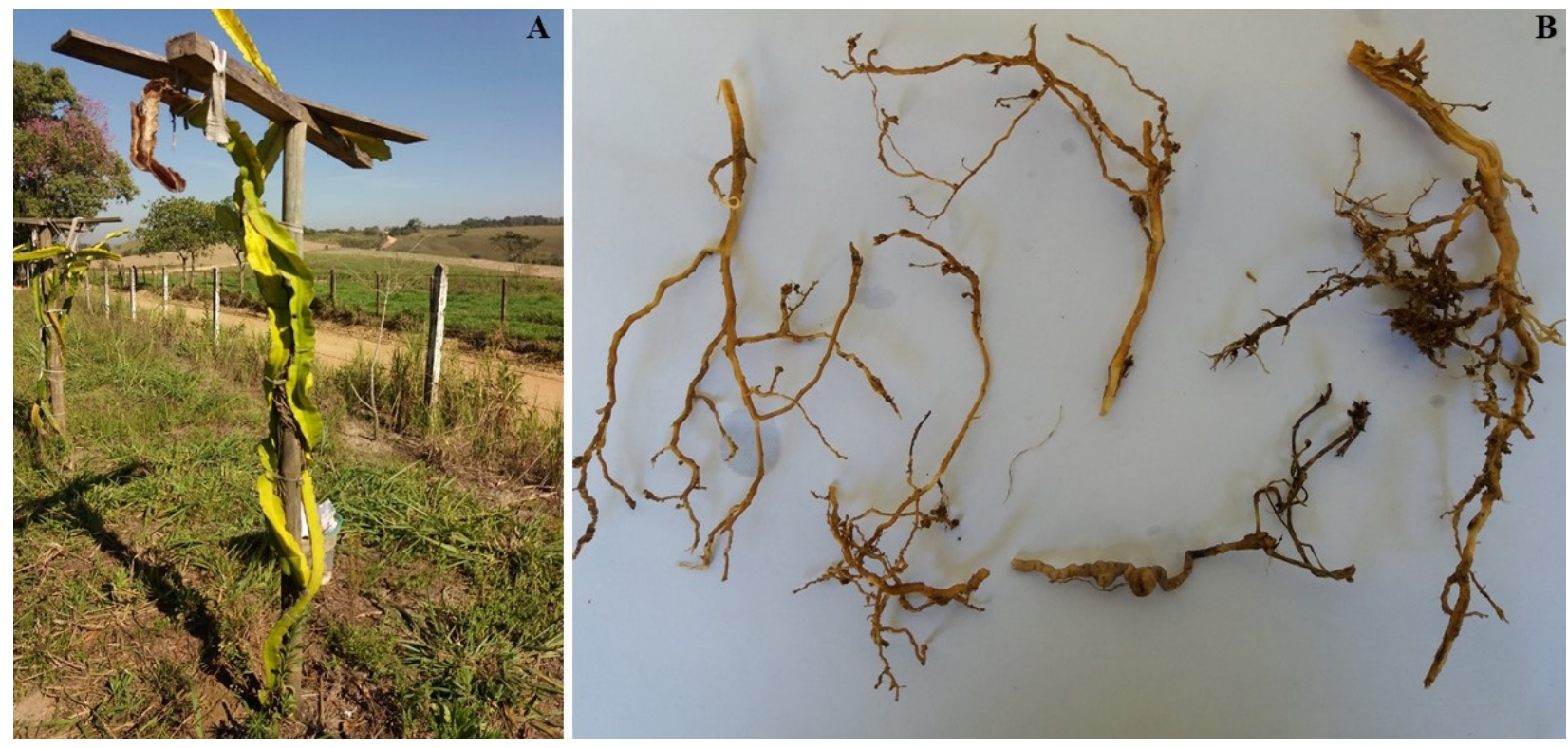

Figure 1. 1A) Pitahaya plants infested with Meloidogyne incognita showing chlorotic-yellowish stems. Some of them were already decaying . 1B) Pitahaya roots showing galls due to $M$. incognita infestation. 
Thus, soil and pitahaya root samples were collected and transported to the Laboratory of Nematology, located at the Department of Plant Pathology and Nematology (ESALQ/USP). The farmer also provided three pitahayarooted cuttings, which were used to extract additional females and maintain Meloidogyne populations. Roots were carefully washed in tap water and egg masses were easily spotted (Figure 2A). Nematodes were recovered from $200 \mathrm{~cm}^{3}$ of soil (JENKINS; TAYLOR, 1967) and 7 $\mathrm{g}$ of roots (COOLEN; D'HERDE, 1972): 1.7 Meloidogyne juveniles $\left(\mathrm{J}_{2}\right)$ per $\mathrm{cm}^{3}$ of soil and 954 eggs $+J_{2}$ per $g$ of roots. Conversely, most galls were found empty probably due the decayed state of the root system, but a few mature females were recovered (Fig. 2B). Ten perineal patterns were obtained, showing slightly squared high dorsal arch. Striae were smooth to wavy and no lateral lines were observed. Striae bending near the vulva edges were also visible (Figure 3). These characteristic traits pointed to M. incognita (KOFOID; WHITE, 1919; CHITWOOD, 1949) (EISENBACK, 1984). To validate our results, esterase phenotype analysis was carried out. For this, 10 mature whitish females were handpicked from roots, placed in extraction solution and maintained on ice. Then, $M$. javanica was included as standard (CARNEIRO et al., 2016) and females were removed from green onions (Allium fistulosum L.) of roots, previously maintained as infested host plants in greenhouse. Isozyme electrophoresis was conducted using a continuous system (ALFENAS; BRUNE, 2006; MACHADO et al., 2010). Meloidogyne javanica exhibited the typical J3 phenotype and females removed from pitahaya exhibited the I1 phenotype, indicating M. incognita.
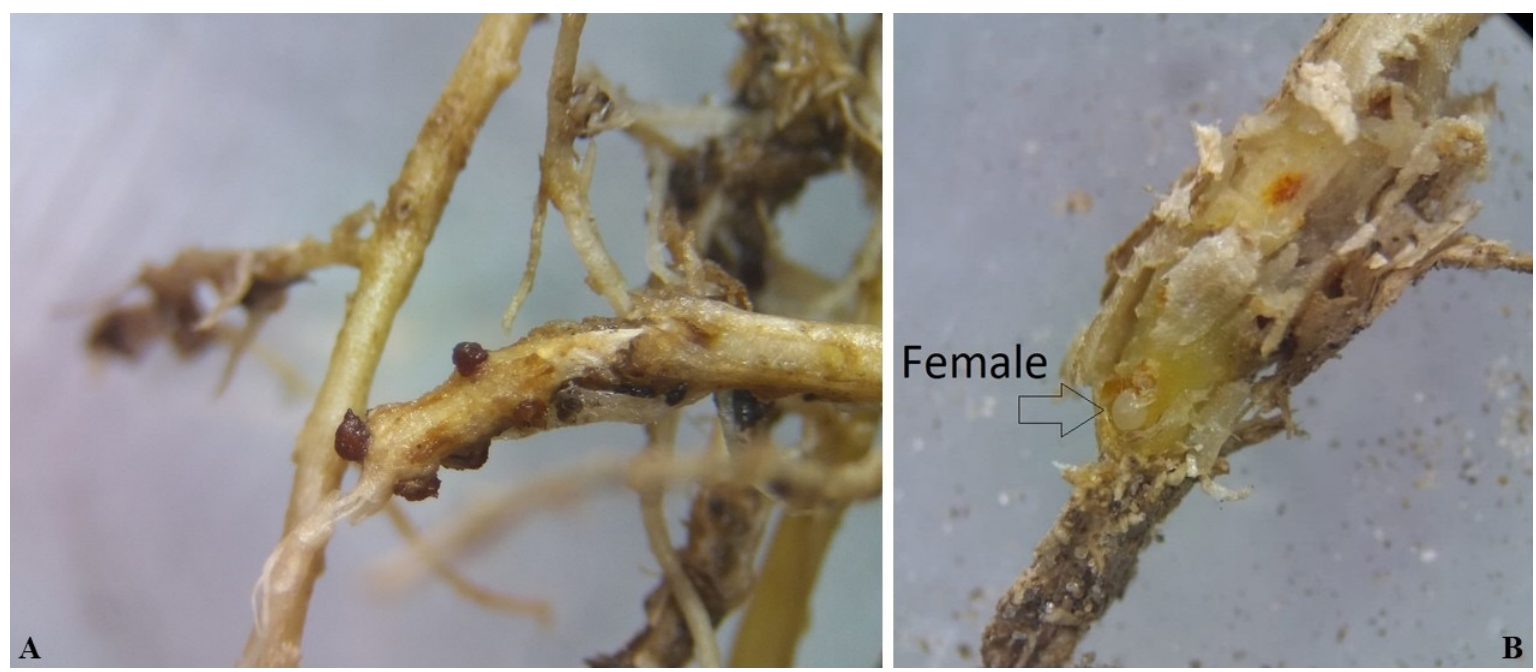

Figure 2. Meloidogyne incognita egg masses (A) and females inside the gall (B) on pitahaya root system.

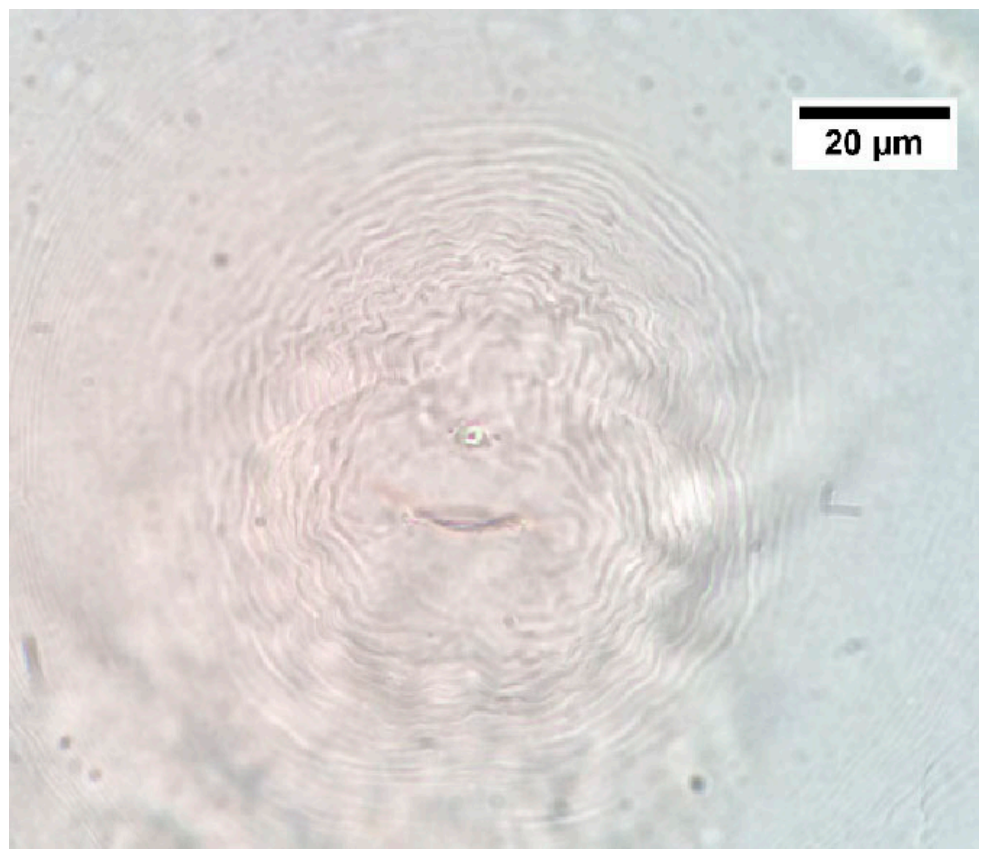

Figure 3. Perineal pattern of Meloidogyne incognita recovered from pitahaya roots. 
We were particularly concerned because the farmer propagated pitahaya planting stem cuttings in pots containing contaminated soil from the field. However, as a result of this research, the farmer started to propagate pitahaya by planting stem cutting directly in the field. To our knowledge, this is the first report of $M$. incognita infesting white pitahaya plants. In addition, only the stunt nematode (Tylenchorhynchus agri Ferris) and $M$. javanica were listed as pathogens of $H$. monacanthus (Lem.) Britton and Rose (syn. S. monacanthus (Lem.) D.R. Hunt, syn. H. polyrhizus (F.A.C. Weber) Britton and Rose) (BALENDRES; BENGOA, 2019, originally reported by ZHANG et al. 2018) (NASCIMENTO et al. 2020). Based on stem and root symptoms of infected pitahaya observed in this survey, M. incognita could be a potential threat to white pitahaya. This is particularly concerning because $M$. incognita is a polyphagous nematodes widespread in tropical countries.

\section{Acknowledgment}

This work was supported by Conselho Nacional de Desenvolvimento Científico e Tecnológico - CNPq and the Coordenação de Aperfeiçoamento de Pessoal de Nível Superior - CAPES.

\section{References}

ALFENAS, A.C.; BRUNE, W. Eletroforese em gel de amido. In: ALFENAS, A.C. Eletroforese e marcadores bioquímicos em plantas e microrganismos. Viçosa: Editora UFV, 2006. p.151-182.

BALENDRES, M.A; BENGOA, J.C. Diseases of dragon fruit (Hylocereus species): etiology and current management options. Crop Protection, Amsterdam, v.126, p.1-32, 2019.

COOLEN, W.A.; D'HERDE, C.J. D. A method for the quantitative extraction of nematodes from plant tissue culture. Ghent: Ghent State Agric. Research Centre; 1972. $77 \mathrm{p}$.

DUARTE, M.H.; QUEIROZ, E.R.; ROCHA, D.A.; COSTA, A.C.; ABREU, C.M.P. Quality of pitaya (Hylocereus undatus) submitted to organic fertilization and stored under refrigeration. Brazilian Journal of Food Technology, Campinas, v.20, e2015115, 2017.

EISENBACK, J.D. Diagnostic characters useful in the identification of the four most common species of rootknot nematodes (Meloidogyne spp.) In: SASSER, J.N.; C.C.; CARTER. An advanced treatise on Meloidogyne: biology and control. Raleigh: North Carolina State University Graphics, 1985. p. 95-112.
JENKINS, W.R.; TAYLOR, D.P. Plant nematology. New York: Reinhold Pub. Corp, 1967. p.270.

MACHADO, A.C.Z ; SIQUEIRA, K.M.S. ; ARAÚJO FILHO, J.V. Methods and techniques in plant nematology: a practical review on methods and techniques in plant -nematology. Saarbrucken: VDM Verlag, 2010. 181p.

NASCIMENTO, D.D.; LOPES, A.P.M.; FERREIRA, R.J.; CARVALHO, V.R.; BOMBONATO, L.T.; DINIZ, D.B.; SILVA, A.A.; WILCKER, S.R.S.; SOARES, L.M. First Report of Meloidogyne javanica Infecting Hylocereus megalanthus in Brazil. Plant Disease, St. Paul, v.104, n.9, p.2526, 2020.

NEPOMOCENO, T.A.R.; PIETROBON, A.J. FERREIRA, C.A.; ZANELATTO, J. O cultivo e a comercialização de pitaya (Hylocereus sp.) no Brasil, com enfoque no estado do Paraná. In: SEMANA DE ENGENHARIA AGRONÔMICA - SEAGRO, 13, 2019, Cascavel. Abstract [...]. Cascavel: FAG Centro Universitário, 2019. p.17-20.

NUNES, E.N.; SOUSA, A.; S. B.; LUCENA, C.M.; SILVA, S.M.; LUCENA, R.F.P.; ALVES, C.A.B.; ALVES, R.E. Pitaia (Hylocereus sp.): uma revisão para o Brasil. Gaia Scientia, João Pessoa, v.8, n.1, p.90-98, 2014.

ORTIZ-HERNÁNDEZ, Y.D.; CARRILLO-SALAZAR, J.A. Pitahaya (Hylocereus spp.): a short review. Comunicata Scientiae, Bom Jesus, v.3, n.4, p.220-237, 2012.

PROHORT. Programa Brasileiro de Modernização do Mercado Hortigranjeiro. Ministério da Agricultura. Dados 2018/2019. Brasília, 2019. Disponível em: dw.ceasa.gov.br. Acesso em: 12 maio 2021.

SONG, H.; ZHENG, Z.; WU, J.; LAI, J.; CHU, Q.; ZHENG, X. White pitaya (Hylocereus undatus) juice attenuates insulin resistance and hepatic steatosis in dietinduced obese mice. Plos One, San Francisco, v.11, n.2, e0149670, 2016.

ZHANG, Y.; LU, X.; HUANG, J.; LIU, Z. First report of a stunt nematode (Tylenchorhynchus agri) from pitaya (Hylocereus polyrhizus) in Guangxi Province of China. Plant Disease, St Paul, v.102, n.12, p.2662, 2018. 